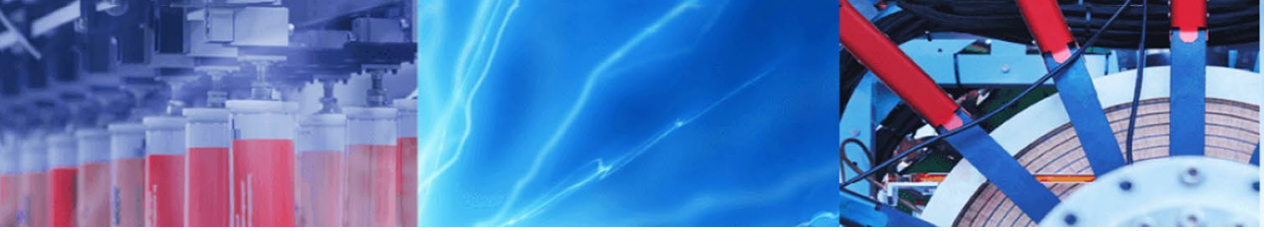

Research Article

\title{
Simultaneous determination of 16 polycyclic aromatic hydrocarbons in groundwater by GC-FID after solid-phase extraction
}

\author{
Fábio Israel Martins Carvalho ${ }^{1,2}$ (D) $\cdot$ Heronides Adonias Dantas Filho ${ }^{1}$ (D) Kelly das Graças Fernandes Dantas $^{1}$ (D)
}

(c) Springer Nature Switzerland AG 2019

\begin{abstract}
Groundwater contamination by polycyclic aromatic hydrocarbons (PAH) may pose a risk to human health, as these compounds are considered to be highly toxic, carcinogenic and/or mutagenic and bioaccumulative. The aim of this study was to evaluate and determine PAH levels in groundwater samples collected from tubular wells in a city of northern Brazil by gas chromatography with flame ionization detector (GC-FID) used by the population for consumption. Sample pre-treatment using solid-phase extraction cartridges was performed in order to promote an enrichment of the PAH fraction of interest and to remove interferences from the matrix to further determine PAH in samples by GC-FID. The results obtained showed that all groundwater samples studied presented PAH levels lower than maximum values allowed by MS 2914/2011 and CONAMA 396/2008. The developed procedure is characterized by low limits of detection and quantification, equal to $0.024-0.113 \mu \mathrm{g} \mathrm{L}^{-1}$ and $0.079-0.378 \mu \mathrm{g} \mathrm{L}^{-1}$, respectively, good linearity $\left(\mathrm{r}^{2}>0.99\right)$. The recoveries obtained for $16 \mathrm{PAH}$ by the addition and recovery method ranged from 85.4 to $105.7 \%$ with good precision (RSD $<5.0 \%$ ). The results of this study showed that the method developed is fast, accurate and robust with high efficiency for identification and determination of $16 \mathrm{PAH}$ in groundwater samples.
\end{abstract}

Keywords Groundwater analysis · Polycyclic aromatic hydrocarbons · Solid-phase extraction · Gas chromatography with flame ionization detector

\section{Introduction}

Groundwater quality has become worse in large urban centers mainly due to inadequate soil use and occupation, generating diverse effluents that return to water bodies, interfering in their quality, and to a lesser extent to seasonality [1, 2]. Therefore, the monitoring of groundwater using chemical analyses is an important measure to evaluate its quality, serving as indicators to identify possible sources of contamination, which can significantly alter the chemical properties of water, compromising the overall balance of the system, causing economic losses and impairing its consumption [3].
According to Rebouças et al. [3], groundwater has been losing quality due to contamination by septic tanks, landfills, contamination by pesticides, fertilizers, saltwater intrusion, pipeline fractures, abandoned or poorly sealed wells, industrial wastes, underground storage of chemicals, leakage of underground fuel tanks, etc. Contamination of aquifers by leakage of oil from underground storage tanks and oil spills, occurring in most cases in its extraction, refinement, transportation and storage, is a worldwide concern and has also been widely discussed in Brazil [4-6].

In the urban area of the city of Belém, state of Pará, a large number of residential condominiums and private households use tubular and excavated Amazonas-type wells as source of groundwater from the Barreiras aquifer

$\triangle$ Kelly das Graças Fernandes Dantas, kdgfernandes@ufpa.br| ${ }^{1}$ Grupo de Espectrometria Analítica Aplicada, Faculdade de Química, Instituto de Ciências Exatas e Naturais, Universidade Federal do Pará, Belém, PA 66075-110, Brazil. ' Universidade Federal Rural da Amazônia, Campus Parauapebas, Parauapebas, PA 68515-000, Brazil. 
(hydrogeological body), being the most explored in the region [7]. It is important to highlight that the Barreiras aquifer, in its great extension, is a shallow, free to semiconfined reservoir, with depth between 25 and $90 \mathrm{~m}$ [8]. In addition, these wells are most often drilled without taking into account the hydrogeological aspects of this aquifer and the proximity of wells (septic or rudimentary) and fuel stations, which are not always built according to technical criteria recommended by the Brazilian Association of Technical Standards (ABNT) $[2,3]$. These factors make the population users of this type of water supply vulnerable to the risks of consuming water contaminated by fuels resulting from leaks in underground storage tanks of reseller and distributor stations, through septic tanks and sewers [7, 9]. These sources of contamination can cause serious environmental impacts due to the contamination of soil and groundwater, compromising the quality of water resources and their use as water supply $[5,10]$.

According to Azevedo [2], several anthropogenic sources can contribute to the presence of polycyclic aromatic hydrocarbons (PAH) in surface water and groundwater. These compounds are fundamentally produced by thermal decomposition based on two important mechanisms: pyrolysis or incomplete combustion and carbonization processes [11]. Studies by Gebara et al. [29], indicate that the main anthropogenic sources of surface and groundwater contamination by $\mathrm{PAH}$ are due to processes of combustion of organic material (particularly the exhaust of diesel and gasoline engines), burning of plant biomass, oil refineries and leakage of oil-derived fuels (gasoline, diesel and lubricating oils).

Organic contaminants, in particular polycyclic aromatic hydrocarbons (PAH), have been extensively investigated in environmental matrixes such as soil, sediments, surface and groundwater due to the toxic action of these compounds on biota and man [12-16]. Studies found in literature on PAH in groundwater are scarce due to the very low concentration in this matrix, compared to the concentrations in litter, sewage, contaminated soils or marine sediments [17-19]. Contamination of this source of water can cause damage to the environment and consequently to human health due to exposure to $\mathrm{PAH}$, as they are substances classified by the International Agency for Research on Cancer (IARC) [20] as carcinogenic and/or mutagenic, highly toxic and bioaccumulative [21-23]. As a consequence, the use of these tubular wells as a source of water supply for human consumption becomes unfeasible [8].

Thus, in view of the potential risks of human exposure to $\mathrm{PAH}$, the application of rapid and reliable analytical techniques for the identification and quantification of $\mathrm{PAH}$ is necessary [4]. In recent years, several authors have used several analytical techniques of high sensitivity to determine PAH in natural waters and environmental samples $[4,10]$. Due to their physical and chemical properties, the most widely used analytical separation techniques for PAH determination have been gas chromatography with flame ionization detector (GC-FID), mass spectrometry (GC-MS), high-performance liquid chromatography (HPLC) with UV-visible detector, diode array (DAD), fluorescence detector and supercritical fluid chromatography (SFC), which can also be associated with other types of detectors [15, 22, 24-28]. According to Lanças [30], chromatography represents the most prominent set of analytical techniques for PAH determination at the present time.

However, it is necessary to introduce a stage for samples to be pretreated, aiming at the extraction and pre-concentration of these contaminants (analyte), allowing the elimination of interfering compounds that may compromise the instrumental analytical technique used [29]. Thus, sample preparation significantly contributes for low limits of detection and high selectivity are achieved in chemical analysis [30].

In general, for PAH determination in water, liquid-liquid extraction (LLE), solid-phase extraction (SPE), stir-bar sorptive extraction (SBSE), membrane-assisted solvent extraction (MASE), liquid-liquid micro-extraction (LLME), and solid-phase micro-extraction (SPME) have been widely used for the extraction and pre-concentration of analytes $[4,10,22,31-34]$.

Considering the relevance of studies of this nature and based on the increased consumption of ground water and with the purpose of obtaining better quality water, the aim of the present study was to evaluate the quality of groundwater collected in tubular wells potentially used for human consumption by the population of five neighborhoods located in the city of Belém (Pará, Brazil) based on the determination of polycyclic aromatic hydrocarbons by gas chromatography with flame ionization detector.

\section{Materials and methods}

\subsection{Description of the study area}

The city of Belém, capital of the state of Pará, located at $1^{\circ} 27^{\prime} 21^{\prime \prime} \mathrm{S}$ and $48^{\circ} 30^{\prime} 14^{\prime \prime} \mathrm{W}$ in northern Brazil, has an area of $1065 \mathrm{~km}^{2}$ and population of more than 1.4 million inhabitants, which together with 5 neighboring municipalities make up the Metropolitan Region of Belém (RMB).

Groundwater samples were collected in five neighborhoods of RMB (Marco, Pedreira, Sacramenta, Canudos and Marambaia), totaling an area of approximately $28.4 \mathrm{~km}^{2}$, where the 17 collection points are located (Fig. 1). 
Fig. 1 Map of the city of Belém and respective collection points distributed in the five neighborhoods under study

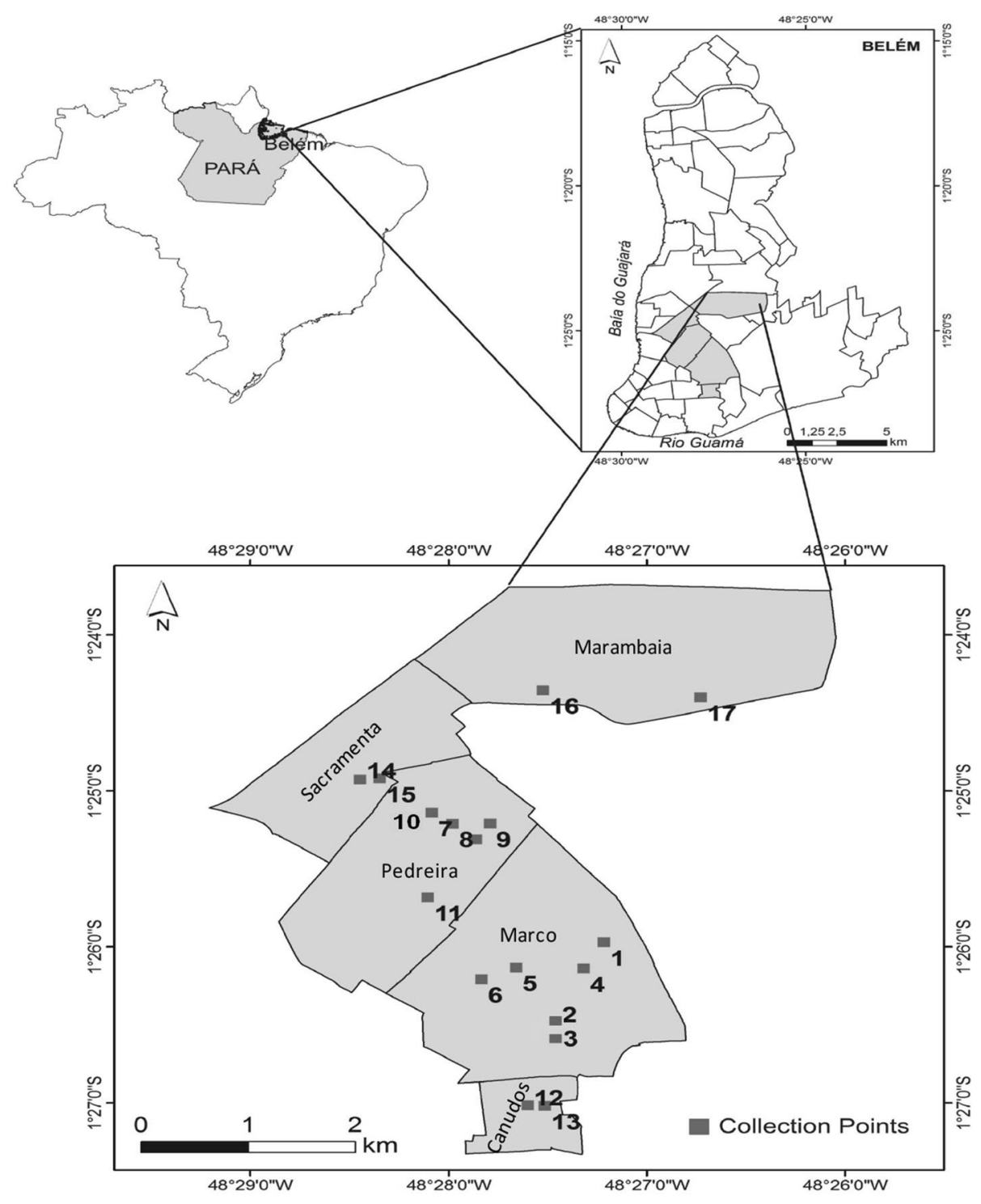

All collection points were georeferenced based on the global positioning system (GPS, Garmin Map 76 model), as shown in Table 1.

These neighborhoods are located near the hydrographic basins of the Una and Tucunduba rivers that cross the city, being a striking hydrographic aspect in the city of Belém. As a consequence of the urban expansion and development, they were transformed into open sewers, receiving domestic and industrial effluents without any previous treatment [7]. The area under study has high population density, old sewage network, large number of resellers of oil-derived fuels (gasoline and diesel) and most residences in the area use in situ sanitation system and groundwater from the Barreiras aquifer for human consumption [8].

\subsection{Instrumentation}

Gas chromatography with flame ionization detector (Trace 1310 , Thermo Scientific, Milan, Italy), equipped with automatic sampler (Tri Plus RSH) and split/splitless injection system, was used to determine $16 \mathrm{PAH}$ in underground water samples. For chromatographic separation, an OV-5 capillary column of fused silica internally coated with dimethylpolysiloxane stationary phase with $5 \%$ phenyl (Ohio Valley Specialty Company, Marietta, Ohio, USA) measuring $30 \mathrm{~m} \times 0.25 \mathrm{~mm}$ i.d. $\times 0.25 \mu \mathrm{m}$ film thickness was used. Helium with $99.99 \%$ purity (Linde, Pará, Brazil) was used as carrier gas at constant flow of $2.0 \mathrm{~mL} \mathrm{~min}$. The Chromeleon 7.0 software (Dionex Corporation, Sunnyvalle, USA) was used for instrumental control of the 
Table 1 Geographic coordinates of the 17 collection points in the five neighborhoods of the city of Belém

\begin{tabular}{|c|c|c|c|}
\hline $\begin{array}{l}\text { Collec- } \\
\text { tion } \\
\text { points }\end{array}$ & Neighborhood & Sample code & $\begin{array}{l}\text { Geographical coordi- } \\
\text { nates }\end{array}$ \\
\hline 1 & Marco & MC1 & $\begin{array}{l}1^{\circ} 25^{\prime} 58,2^{\prime \prime} \mathrm{Se} \\
48^{\circ} 27^{\prime} 12,9^{\prime \prime} \mathrm{W}\end{array}$ \\
\hline 2 & Marco & MC2 & $\begin{array}{l}1^{\circ} 26^{\prime} 28,6^{\prime \prime} \mathrm{Se} \\
48^{\circ} 27^{\prime} 27,5^{\prime \prime} \mathrm{W}\end{array}$ \\
\hline 3 & Marco & MC3 & $\begin{array}{l}1^{\circ} 26^{\prime} 29,1^{\prime \prime} \mathrm{Se} \\
48^{\circ} 27^{\prime} 27,2^{\prime \prime} \mathrm{W}\end{array}$ \\
\hline 4 & Marco & MC4 & $\begin{array}{l}1^{\circ} 26^{\prime} 08,3^{\prime \prime} \mathrm{S} \mathrm{e} \\
48^{\circ} 27^{\prime} 19,1^{\prime \prime} \mathrm{W}\end{array}$ \\
\hline 5 & Marco & MC5 & $\begin{array}{l}1^{\circ} 26^{\prime} 07,9^{\prime \prime} \mathrm{S} \mathrm{e} \\
48^{\circ} 27^{\prime} 39,5^{\prime \prime} \mathrm{W}\end{array}$ \\
\hline 6 & Marco & MC6 & $1^{\circ} 26^{\prime} 12,4^{\prime \prime}$ S e $48^{\circ} 27^{\prime} 50^{\prime \prime} \mathrm{W}$ \\
\hline 7 & Pedreira & PR1 & $\begin{array}{l}1^{\circ} 25^{\prime} 07,5^{\prime \prime} \mathrm{Se} \\
48^{\circ} 27,4^{\prime} 41^{\prime \prime} \mathrm{W}\end{array}$ \\
\hline 8 & Pedreira & PR2 & $\begin{array}{l}1^{\circ} 25^{\prime} 19,3^{\prime \prime} \mathrm{Se} \\
48^{\circ} 27^{\prime} 29,5^{\prime \prime} \mathrm{W}\end{array}$ \\
\hline 9 & Pedreira & PR3 & $\begin{array}{l}1^{\circ} 25^{\prime} 12,6^{\prime \prime} \mathrm{Se} \\
48^{\circ} 27^{\prime} 47,4^{\prime \prime} \mathrm{W}\end{array}$ \\
\hline 10 & Pedreira & PR4 & $\begin{array}{l}1^{\circ} 25^{\prime} 18,7^{\prime \prime} \mathrm{Se} \\
48^{\circ} 27^{\prime} 51,6^{\prime \prime} \mathrm{W}\end{array}$ \\
\hline 11 & Pedreira & PR5 & $1^{\circ} 25^{\prime} 41^{\prime \prime}$ S e $48^{\circ} 28^{\prime} 06,2^{\prime \prime S}$ \\
\hline 12 & Canudos & CD1 & $1^{\circ} 27^{\prime} 00,9^{\prime \prime}$ S e $48^{\circ} 27^{\prime} 36^{\prime \prime} \mathrm{W}$ \\
\hline 13 & Canudos & $\mathrm{CD} 2$ & $\begin{array}{l}1^{\circ} 27^{\prime} 01,1^{\prime \prime} \mathrm{Se} \\
48^{\circ} 27^{\prime} 30,8^{\prime \prime} \mathrm{W}\end{array}$ \\
\hline 14 & Sacramenta & ST1 & $1^{\circ} 25^{\prime} 05^{\prime \prime}$ S e $48^{\circ} 28^{\prime} 05,7^{\prime \prime} \mathrm{W}$ \\
\hline 15 & Sacramenta & $\mathrm{ST} 2$ & $\begin{array}{l}1^{\circ} 24^{\prime} 55,3^{\prime \prime} \mathrm{Se} \\
48^{\circ} 28^{\prime} 20,8^{\prime \prime} \mathrm{W}\end{array}$ \\
\hline 16 & Marambaia & MB1 & $1^{\circ} 24^{\prime} 28,2^{\prime \prime}$ S e $48^{\circ} 27^{\prime} 32^{\prime \prime} \mathrm{W}$ \\
\hline 17 & Marambaia & MB2 & $\begin{array}{l}1^{\circ} 24^{\prime} 32,6^{\prime \prime} \mathrm{S} \mathrm{e} \\
48^{\circ} 26^{\prime} 42,6^{\prime \prime} \mathrm{W}\end{array}$ \\
\hline
\end{tabular}

chromatographic system and data acquisition in Windows platform.

A system for vacuum SPE with capacity for 12 C-18 cartridges (Visiprep ${ }^{\mathrm{TM}}$, Supelco, Bellefonte, PA, USA) was used in the procedure for extracting $\mathrm{PAH}$ in groundwater samples for further analysis by GC-FID.

\subsection{Gas chromatographic conditions}

The optimum chromatographic conditions obtained that allowed the best separation and resolution of peaks that enabled the identification and quantification of $16 \mathrm{PAH}$ of interest are described in Table 2. All measurements were performed in triplicate.

\subsection{Reagents and standards}

All solutions were prepared using analytical grade reagents and ultrapure water (specific resistivity of $18.2 \mathrm{M} \Omega$ $\mathrm{cm}$ ) obtained by Milli-Q purification system (Millipore, Billerica, MA, USA).

The PAH certified mixed standard was acquired of $2000 \mu \mathrm{g} \mathrm{mL}^{-1}$ (99\% purity) in dichloromethane solution (lot LB66674) (Supelco, Bellefonte, PA, USA) containing naphthalene (Naf), 2-bromonaphthalene (2-BrNaf), acenaphthylene (Aci), acenaphthene (Ace), fluorene (Flu), phenanthrene (Fen), anthracene (Ant), fluoranthene (FIt), pyrene (Pyr), benzo [a] anthracene (BaA), chrysene (Cry), benzo [b] fluoranthene $(\mathrm{BbF})$, benzo [a] pyrene $(\mathrm{BaP})$, indeno $[1,2,3-\mathrm{cd}]$ pyrene (Ind), dibenzo $[\mathrm{a}, \mathrm{h}]$ anthracene (DBahA) and benzo $[\mathrm{g}, \mathrm{h}, \mathrm{i}]$ perylene (BghiP) was used to prepare a $10 \mathrm{mg} \mathrm{L}^{-1}$ stock solution.

Dichloromethane (99.5\%) HPLC grade (Tedia Way, Fairfield, USA) was used in the preparation of stock solution

Table 2 Chromatographic conditions used in the determination of 16 PAH by GC-FID

\begin{tabular}{|c|c|}
\hline Programming column temperature & 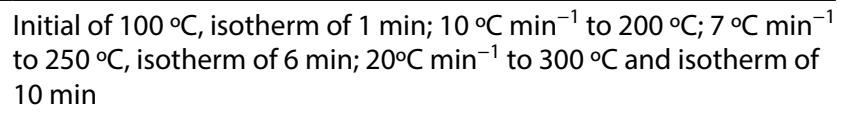 \\
\hline Equilibration time & $0.5 \mathrm{~min}$ \\
\hline Injection & Split 1:30 (2,0 $\mu \mathrm{L})$ \\
\hline Injector temperature & $270^{\circ} \mathrm{C}$ \\
\hline FID temperature & $320^{\circ} \mathrm{C}$ \\
\hline Total gas flow carrier $(\mathrm{He})$ & $60 \mathrm{~mL} \min ^{-1}$ \\
\hline Gas pressure carrier & $85 \mathrm{kPa}$ \\
\hline Total gas flow synthetic air & $350 \mathrm{~mL} \mathrm{~min}-1$ \\
\hline Gas pressure synthetic air & $40 \mathrm{kPa}$ \\
\hline Total gas flow Hydrogen $\left(\mathrm{H}_{2}\right)$ & $35 \mathrm{~mL} \mathrm{\operatorname {min } ^ { - 1 }}$ \\
\hline Gas pressure hydrogen & $60 \mathrm{kPa}$ \\
\hline Total gas flow make-up $\left(\mathrm{N}_{2}\right)$ & $40 \mathrm{~mL} \min ^{-1}$ \\
\hline Gas pressure make-up & $60 \mathrm{kPa}$ \\
\hline Total analysis time & $31.64 \mathrm{mim}$ \\
\hline
\end{tabular}


and PAH intermediate solutions. Stock and intermediate solutions were stored in Teflon-sealed amber glass vials under refrigeration at $4{ }^{\circ} \mathrm{C}$ and protected from light.

C-18 cartridges $(200 \mathrm{mg} / 3.0 \mathrm{~mL})$ with $33 \mu \mathrm{m}$ reverse phase polymer porosity (Strata X, Phenomenex, USA) were used for PAH extraction and pre-concentration in groundwater samples.

Polytetrafluoroethylene membranes (PTFE) of $0.45 \mu \mathrm{m}$ porosity (Millipore Phenomenex, USA) were used to filter all solvents used in analytical determinations and samples.

Polyethylene volumetric flasks, glassware, vial vials and micropipette tips were washed with tap water, then with deionized water and then immersed in $10 \%(\mathrm{v} / \mathrm{v}) \mathrm{HNO}_{3}$ solution for $24 \mathrm{~h}$. Subsequently, these materials were abundantly washed with deionized water and dried in a laminar flow hood. For the removal of impurities from the glass micro-syringe and from the GC-FID injection line (Tedia Way, Fairfield, OH, USA), acetone was used.

\subsection{Sampling}

Seventeen groundwater samples were collected from tubular wells (Marco: 6; Pedreira: 5; Sacramenta: 2; Canudos: 2; Marambaia: 2), considered the seasonal period of rainfall in the region. Sampling was performed according to the Standard Methods for the Examination of Water and Wastewater from the American Public Health Association (APHA) [35].

Samples were collected in $1000 \mathrm{~mL}$ amber glass bottles previously sterilized and decontaminated in $10 \%$ (v/v) $\mathrm{HNO}_{3}$ solution for PAH determination. After collection, all samples were duly identified, preserved and kept under refrigeration at $4{ }^{\circ} \mathrm{C}$ and protected from light until extraction.

\subsection{Sample preparation}

The extraction procedure of PAH in groundwater samples using solvent extraction was adapted from the United States Environmental Protection Agency method 3535A (USEPA) [36] with the purpose of optimizing the process, reducing solvent costs and analysis time. The proposed solid-phase extraction procedure is shown in Fig. 2. The adsorbent used for extraction was C-18 (octadecylsilane) of $200 \mathrm{mg}$ in a $3.0 \mathrm{~mL}$ cartridge.

A volume of $100 \mathrm{~mL}$ of sample was filtered through $0.45 \mu \mathrm{m}$ membranes for further extraction in C-18 cartridge. In the extraction procedure, solvents dichloromethane (DCM) and methanol (MeOH) were used. In the elution step, $10 \mathrm{~mL}$ of a 4:1 (v/v) DCM/MeOH extraction solution per sample for removal of the analytes of interest were used.
The accuracy of the proposed procedure was evaluated using the addition and recovery method in samples enriched with 3.0; 30 and $70 \mu \mathrm{g} \mathrm{L}^{-1}$ of PAH for further GCFID analysis. Analytical blank was prepared using the same procedure proposed for samples, but without the addition of analyte.

\subsection{Analysis of PAH by GC-FID}

The amount of PAH in groundwater samples was determined by the external calibration method using an external standard of a mixture of 16 certified PAH based on the FID signal/noise ratio response and its identification was confirmed by the retention time. Analytical curves were constructed from standard solutions of 5.0; 10; 50; 100; $300 ; 400$ and $500 \mu \mathrm{g} \mathrm{L}^{-1}$ of PAH. Each point of the analytical curve was injected in triplicate.

The PAH determination in samples was adapted from the USEPA method 8100 (1986) [37], following the international acceptance criteria regarding accuracy and precision. The acceptance criterion in the verification of analytical curves was based on the FID response for all 16 PAH before the analyses of samples, whose variation should be less than $20 \%$.

\section{Results and discussion}

\subsection{Evaluation of the analytical procedure for PAH determination}

Initially, a standard $50 \mathrm{\mu g} \mathrm{L}^{-1}$ solution containing $16 \mathrm{PAH}$ was used in the optimization of the best chromatographic conditions in order to obtain the best resolution possible in the simultaneous identification of $16 \mathrm{PAH}$. The instrumental parameters optimized for the adequacy of the chromatographic system were the programming of the column temperature (isotherm, gradient and ramp), injector temperature and FID temperature.

Figure 3 shows the chromatographic profile obtained for a standard $50 \mu \mathrm{g} \mathrm{L}^{-1} \mathrm{PAH}$ solution according to the chromatographic conditions established in this study (see Table 2). Figure 3 shows that the $16 \mathrm{PAH}$ present in the standard solution with their respective retention times $\left(T_{R}\right)$ were identified.

It could be observed in Fig. 3 that the highest sensitivities were obtained for naphthalene, 2-bromonaphthalene, acenaphthylene, acenaphthene, fluorene, phenanthrene, anthracene, fluoranthene, pyrene, benzo [a] anthracene and indene $[1,2,3-\mathrm{cd}]$ pyrene, when compared to chrysene, benzo [b] fluoranthene, benzo [a] pyrene, dibenzo $[a, h]$ anthracene and benzo $[g, h, i]$ perylene. 
Fig. 2 Flowchart of the procedure for extraction of PAH from groundwater samples by SPE. (Adapted from USEPA method 3535A, 1998 [36])

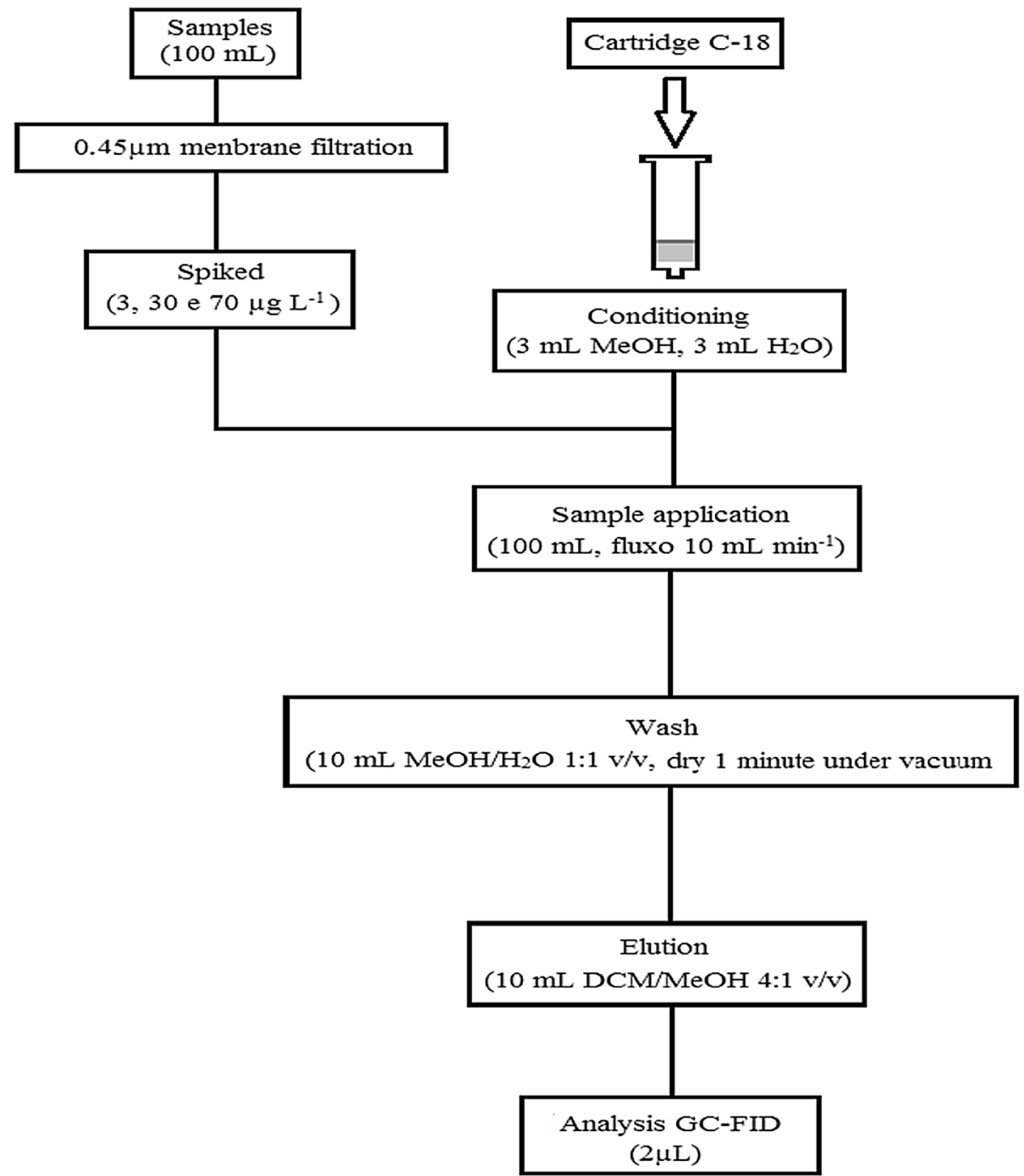

The total time of analysis was $31.64 \mathrm{~min}$, where the first and the last compound to elute were naphthalene and benzo $[\mathrm{g}, \mathrm{h}, \mathrm{i}]$ perylene, with retention times $\left(\mathrm{T}_{\mathrm{R}}\right)$ of 4.25 and 28.37 min, respectively.

Retention times for the $16 \mathrm{PAH}$ ranged from 4.25 to $28.37 \mathrm{~min}$. PAH with low molecular weight values showed the lowest retention times, characterized by being the most volatile and with the highest solubility in water (see Table 3).

Figure 4 shows the chromatogram obtained from the dichloromethane solvent used in the preparation of standard solutions for the construction of analytical curves. The chromatographic profile obtained shows the absence of $\mathrm{PAH}$ in the dichloromethane solvent.

\subsection{Analytical performance}

Analytical curves were experimentally obtained from seven standard solutions of $16 \mathrm{PAH}$ at concentrations ranging from 5.0 to $500 \mu \mathrm{g} \mathrm{L}^{-1}$. The analytical curves obtained for all PAH under study presented adequate linearities, since the correlation coefficients $\left(r^{2}\right)$ values ranged from 0.9994 to 0.9998 . Under the established analytical conditions, the limits of detection (LOD) and quantification (LOQ) were calculated from the mean of the relative areas of analytical white noise and their standard deviations by equations $3 \times s / b$ and $10 \times s / b$, respectively, where $s$ is the standard deviation of ten analytical white readings and the angular coefficient of the analytical curve [38]. LOD and LOQ obtained for these compounds ranged from $0.024-0.113 \mu \mathrm{g} \mathrm{L}^{-1}$ to $0.079-0.378 \mu \mathrm{g} \mathrm{L}^{-1}$, respectively.

Table 4 shows the merit figures obtained for the determination of $16 \mathrm{PAH}$ in groundwater samples.

The recoveries obtained by the addition and recovery method ranged from 85.4 to $105.7 \%$, with relative standard deviation of measurements ( $\% R S D, n=3$ ) less than $5 \%$. The recovery results obtained by the proposed analytical method showed that the pre-concentration 


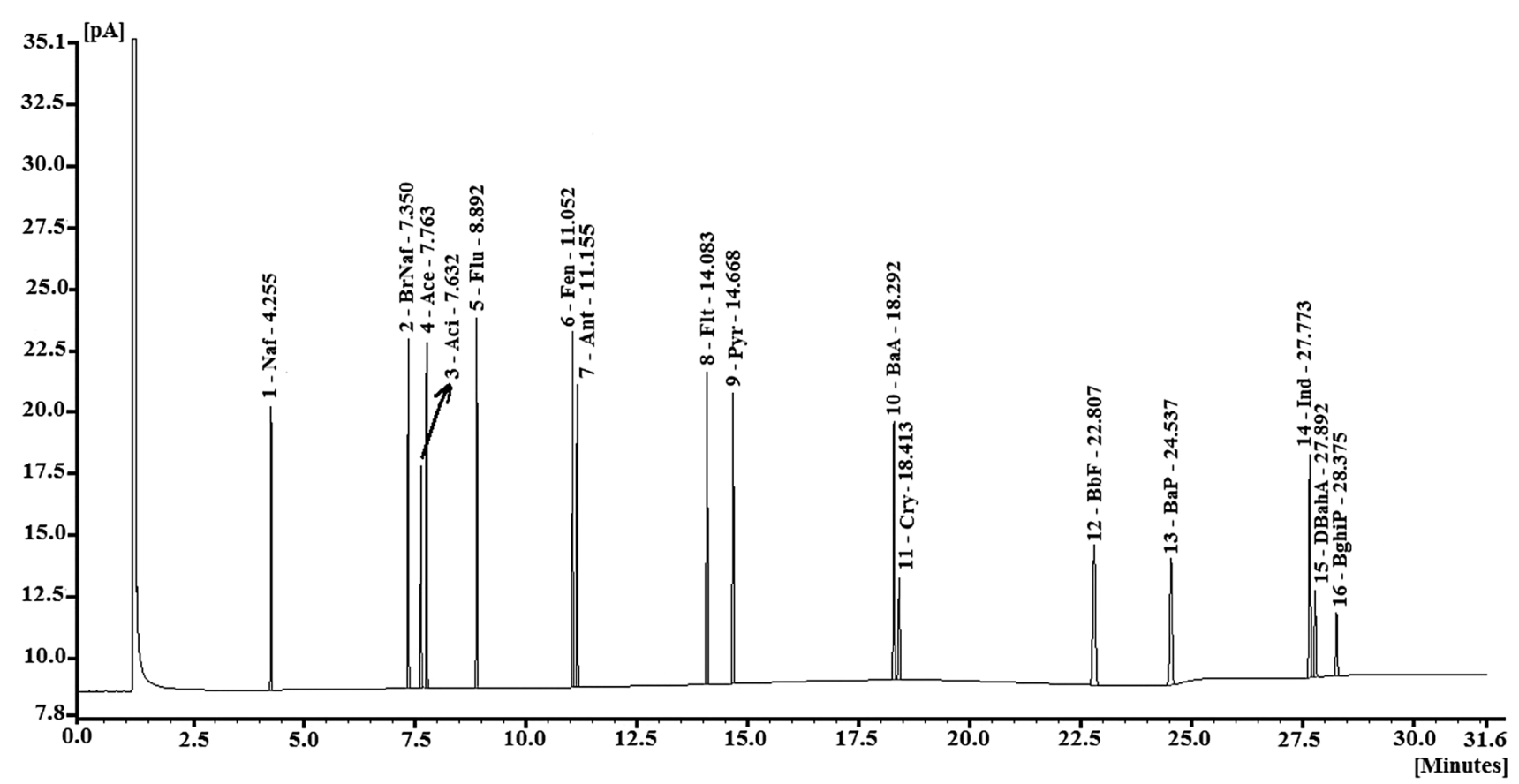

Fig. 3 Chromatographic profile obtained for a standard solution of the $50 \mu \mathrm{g} \mathrm{L}^{-1}$ content $16 \mathrm{HPA}$

Table 3 Average retention time $\left(T_{R}\right)$ of PAH obtained from a standard $50 \mu \mathrm{g} \mathrm{L}^{-1}$ solution identified by GC-FID

\begin{tabular}{lll}
\hline Peak & PAH & $\mathrm{T}_{\mathrm{R}}$ (min) \\
\hline 1 & Naphthalene (Naf) & 4.25 \\
2 & 2-Bromonaphthalene (2-BrNaf) & 7.35 \\
3 & Acenaphthylene (Aci) & 7.63 \\
4 & Acenaphtene (Ace) & 7.76 \\
5 & Fluorene (Flu) & 8.89 \\
6 & Fenanthrene (Fen) & 11.05 \\
7 & Anthracene (Ant) & 11.15 \\
8 & Fluoranthene (Flt) & 14.08 \\
9 & Pyrene (Pyr) & 14.67 \\
10 & Benzo[a]anthracene (BaA) & 18.29 \\
11 & Chrysene (Cry) & 18.41 \\
12 & Benzo[b]fluoranthene (BbF) & 22.81 \\
13 & Benzo[a]pyrene (BaP) & 24.54 \\
14 & Indeno[1,2,3-cd]pyrene (Ind) & 27.77 \\
15 & Dibenzo[a,h]anthracene (DBahA) & 27.89 \\
16 & Benzo[g,h,i]perylene (BghiP) & 28.37 \\
\hline
\end{tabular}

and extraction procedure by SPE is feasible for PAH determination in groundwater samples by GC-FID. The recoveries obtained for the $16 \mathrm{PAH}$ are shown in Table 5.

\subsection{Total concentration of PAH in groundwater samples}

Figure 5 shows the chromatographic profile obtained after SPE procedure of groundwater sample collected in the neighborhood of Pedreira (PR2) according to the established GC-FID chromatographic conditions. It could be seen in Fig. 5 that only six PAH were identified in this sample.

The mean values of results corresponding to the 16 $\mathrm{PAH}$ determined in groundwater samples collected in the neighborhoods of Marco, Pedreira, Sacramenta, Canudos and Marambaia are presented in Table 6 . The results were compared with the two reference standards of water quality required by the Brazilian Legislation $[39,40]$.

All samples studied presented PAH levels lower than the maximum values allowed by MS 2914/2011 [39] and CONAMA 396/2008 [40]. However, it is important to note that MC1, MC4, MC5, MC6 samples collected in the neighborhood of Marco; PR1, PR2, PR3 and PR5 collected in the neighborhood of Pedreira; $C D 1$ and $C D 2$ in the neighborhood of Canudos, presented levels for some PAH under study, which may be due to the presence of anthropic polluting processes [16]. In the neighborhoods of Sacramenta and Marambaia, all samples presented PAH levels below the limit of detection.

The results presented in Table 6 show that PAH with the highest and lowest content in groundwater samples were naphthalene (Naf) and acenaphthylene (Aci), with 36.4 


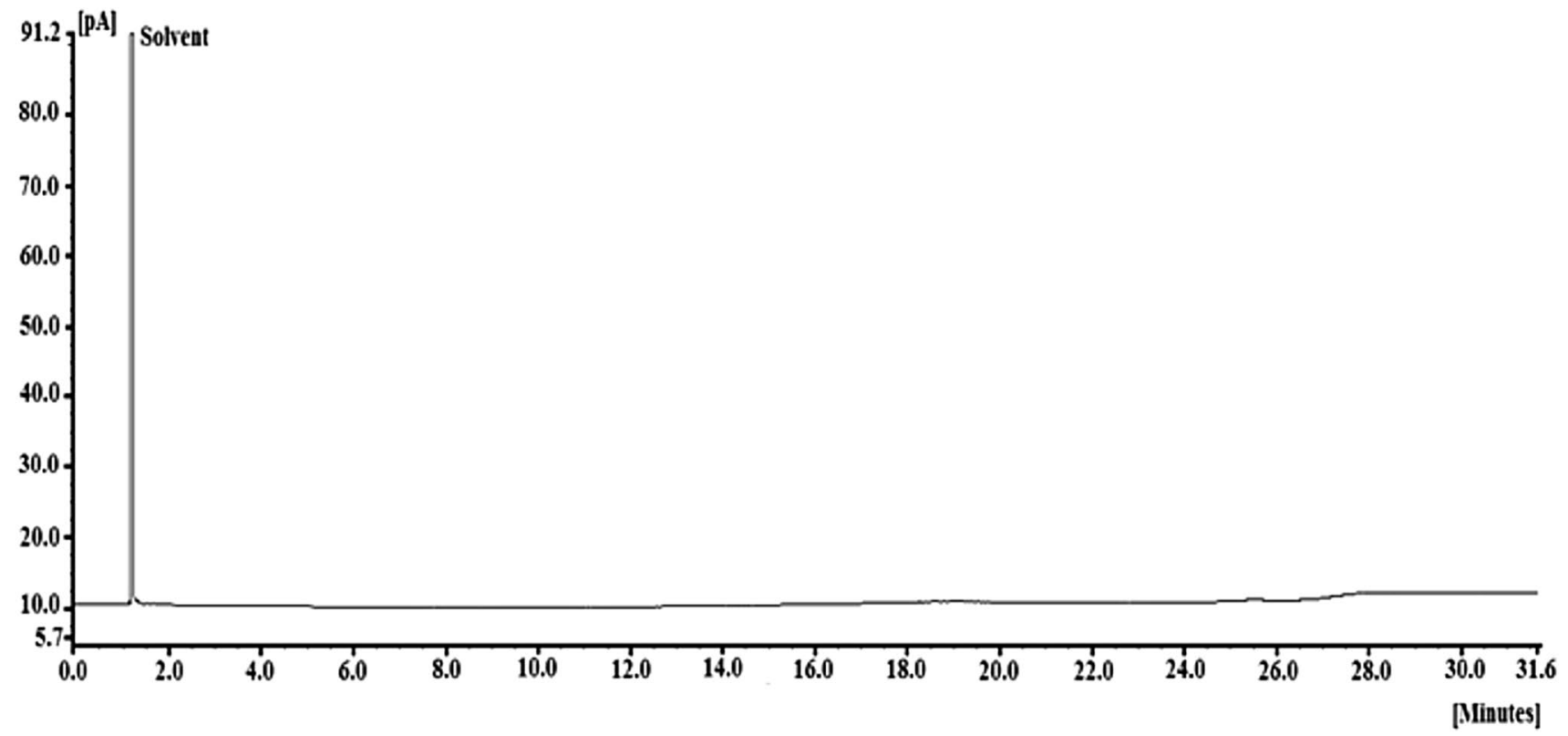

Fig. 4 Chromatographic profile of the dichloromethane solvent obtained by GC-FID

Table 4 Figures of merit obtained for the determination of $16 \mathrm{PHA}$ by GC-FID

\begin{tabular}{|c|c|c|c|c|}
\hline $\mathrm{PHA}$ & $r^{2}$ & Slope & $\operatorname{LOD}\left(\mu \mathrm{g} \mathrm{L}^{-1}\right)$ & $\mathrm{LOQ}\left(\mu \mathrm{g} \mathrm{L}^{-1}\right)$ \\
\hline Naphthalene & 0.9994 & 0.0003 & 0.032 & 0.105 \\
\hline $\begin{array}{l}\text { 2-Bromonaphtha- } \\
\text { lene }\end{array}$ & 0.9997 & 0.0003 & 0.042 & 0.140 \\
\hline Acenaphthylene & 0.9995 & 0.0002 & 0.047 & 0.158 \\
\hline Acenaphtene & 0.9995 & 0.0003 & 0.053 & 0.176 \\
\hline Fluorene & 0.9997 & 0.0004 & 0.024 & 0.079 \\
\hline Fenanthrene & 0.9996 & 0.0004 & 0.036 & 0.121 \\
\hline Anthracene & 0.9998 & 0.0003 & 0.044 & 0.147 \\
\hline Fluoranthene & 0.9998 & 0.0004 & 0.026 & 0.088 \\
\hline Pyrene & 0.9997 & 0.0004 & 0.033 & 0.110 \\
\hline Benzo[a]anthracene & 0.9997 & 0.0004 & 0.025 & 0.083 \\
\hline Chrysene & 0.9998 & 0.0001 & 0.095 & 0.316 \\
\hline $\begin{array}{l}\text { Benzo[b]fluoran- } \\
\text { thene }\end{array}$ & 0.9998 & 0.0004 & 0.035 & 0.116 \\
\hline Benzo[a]pyrene & 0.9997 & 0.0003 & 0.045 & 0.148 \\
\hline $\begin{array}{l}\text { Indeno[1,2,3-cd] } \\
\text { pyrene }\end{array}$ & 0.9995 & 0.0003 & 0.052 & 0.172 \\
\hline $\begin{array}{l}\text { Dibenzo[a,h]anthra- } \\
\text { cene }\end{array}$ & 0.9997 & 0.0001 & 0.106 & 0.353 \\
\hline Benzo[g,h,i]perylene & 0.9997 & 0.0001 & 0.113 & 0.378 \\
\hline
\end{tabular}

$L O D=$ limit of detection; $L O Q=$ limit of quantification $r^{2}=$ correlation coefficient; slope $=$ angular coefficient and $2.8 \mu \mathrm{g} \mathrm{L}^{-1}$, respectively. The neighborhoods of Marco, Pedreira and Canudos obtained the highest sums of PAH ( $\mathrm{PAH})$, with $173.6,175.7$ and $52.5 \mu \mathrm{g} \mathrm{L}^{-1}$, respectively. This scenario may be related to the combustion processes of biomass and fossil fuels, as well as occurrences of fuel leaks (gasoline, diesel, lubricating oil) at fuel retailers located in the region under study $[4,5,29,41,42]$.

\section{Conclusion}

The solid phase extraction (SPE) used in extraction of PAH and preconcentration in groundwater combined with gas chromatography with flame ionization detector (GCFID) resulted in a fast, accurate and robust method with high efficiency for determination of $16 \mathrm{PAH}$. The results of accuracy, precision, linearity, limit of detection (LOD) and limit of quantification (LOQ) and recovery indicated the viability of the method used. The results obtained for the $16 \mathrm{PAH}$ investigated showed that all samples met the limits established by Ordinance MS 2914/2011 and CONAMA Resolution 396/2008. However, samples collected in the neighborhoods of Marco (MC1, MC4, MC5 and MC6), Pedreira (PR1, PR2, PR3 and PR5) and Canudos (CD1 and $\mathrm{CD} 2$ ) presented $\mathrm{PAH}$ levels evidencing a possible contamination by oil-derived fuels. 
Table 5 Recoveries obtained for 16 PHA for method of addition and recovery in groundwater samples by GC-FID $\left(\mu g \mathrm{~L}^{-1} \pm \mathrm{SD}, n=3\right)$

\begin{tabular}{|c|c|c|c|c|c|c|}
\hline \multirow[t]{2}{*}{ PAH } & \multicolumn{2}{|c|}{$\begin{array}{l}\text { Sample } 1 \\
\text { Spiked }\left(3.0 \mu \mathrm{g} \mathrm{L}^{-1}\right)\end{array}$} & \multicolumn{2}{|c|}{$\begin{array}{l}\text { Sample } 2 \\
\text { Spiked }\left(30 \mu \mathrm{g} \mathrm{L}^{-1}\right)\end{array}$} & \multicolumn{2}{|c|}{$\begin{array}{l}\text { Sample } 3 \\
\text { Spiked }\left(70 \mu \mathrm{g} \mathrm{L}^{-1}\right)\end{array}$} \\
\hline & Found & Recovery (\%) & Found & Recovery (\%) & Found & Recovery (\%) \\
\hline Naphthalene & $2.61 \pm 0.04$ & $87.1 \pm 1.35$ & $31.9 \pm 0.74$ & $105.5 \pm 1.50$ & $66.3 \pm 0.43$ & $94.7 \pm 0.65$ \\
\hline 2-Bromonaphthalene & $2.60 \pm 0.03$ & $86.9 \pm 1.07$ & $31.7 \pm 0.82$ & $105.7 \pm 2.73$ & $65.4 \pm 0.98$ & $93.4 \pm 1.40$ \\
\hline Acenaphthylene & $2.67 \pm 0.03$ & $89.1 \pm 1.15$ & $29.4 \pm 0.17$ & $97.8 \pm 0.69$ & $65.5 \pm 2.08$ & $93.2 \pm 2.97$ \\
\hline Acenaphtene & $2.57 \pm 0.03$ & $85.8 \pm 1.02$ & $29.3 \pm 0.21$ & $97.5 \pm 0.66$ & $67.9 \pm 0.32$ & $97.1 \pm 0.45$ \\
\hline Fluorene & $2.73 \pm 0.05$ & $91.1 \pm 1.57$ & $28.5 \pm 0.25$ & $95.1 \pm 0.84$ & $64.5 \pm 0.96$ & $92.1 \pm 1.38$ \\
\hline Fenanthrene & $2.82 \pm 0.03$ & $94.1 \pm 1.17$ & $29.4 \pm 0.15$ & $98.1 \pm 0.51$ & $63.6 \pm 0.25$ & $90.9 \pm 0.36$ \\
\hline Anthracene & $2.72 \pm 0.04$ & $90.5 \pm 1.34$ & $28.5 \pm 0.36$ & $95.0 \pm 1.20$ & $64.7 \pm 0.85$ & $92.4 \pm 1.21$ \\
\hline Fluoranthene & $2.84 \pm 0,03$ & $94.5 \pm 1.17$ & $27.9 \pm 0.08$ & $93.0 \pm 0.33$ & $64.2 \pm 0.47$ & $92.0 \pm 0.67$ \\
\hline Pyrene & $2,81 \pm 0.04$ & $93.8 \pm 1.50$ & $28.4 \pm 0.12$ & $94.9 \pm 0.51$ & $65.1 \pm 0.93$ & $93.0 \pm 1.33$ \\
\hline Benzo[a]anthracene & $2.85 \pm 0.03$ & $95.0 \pm 0.88$ & $27.6 \pm 0.15$ & $91.0 \pm 2.08$ & $65.3 \pm 1.34$ & $93.1 \pm 1.92$ \\
\hline Chrysene & $2.69 \pm 0.03$ & $89.5 \pm 1.02$ & $28.7 \pm 0.24$ & $95.6 \pm 0.97$ & $67.8 \pm 1.10$ & $96.9 \pm 1.57$ \\
\hline Benzo[b]fluoranthene & $2.73 \pm 0.02$ & $91.1 \pm 0.84$ & $28.1 \pm 0.20$ & $93.5 \pm 0.84$ & $63.8 \pm 0.96$ & $91.2 \pm 1.38$ \\
\hline Benzo[a]pyreno & $2.85 \pm 0.03$ & $95.1 \pm 1.07$ & $28.2 \pm 0.78$ & $94.1 \pm 3.21$ & $60.0 \pm 0.24$ & $85.7 \pm 0.34$ \\
\hline Indeno[1,2,3-cd]pyrene & $2.57 \pm 0.02$ & $85.7 \pm 0.83$ & $27.7 \pm 0.08$ & $92.3 \pm 0.33$ & $68.1 \pm 1.48$ & $97.3 \pm 2.11$ \\
\hline Dibenzo[a,h]anthracene & $2.52 \pm 0.03$ & $86.7 \pm 1.02$ & $28.7 \pm 0.61$ & $95.9 \pm 2.50$ & $66.6 \pm 1.25$ & $95.1 \pm 1.78$ \\
\hline Benzo[g,h,i]peryleno & $2.54 \pm 0.02$ & $85.4 \pm 0.84$ & $28.5 \pm 0.41$ & $95.1 \pm 1.67$ & $59.9 \pm 0.71$ & $85.6 \pm 1.01$ \\
\hline
\end{tabular}

$\mathrm{SD}=$ standard deviation

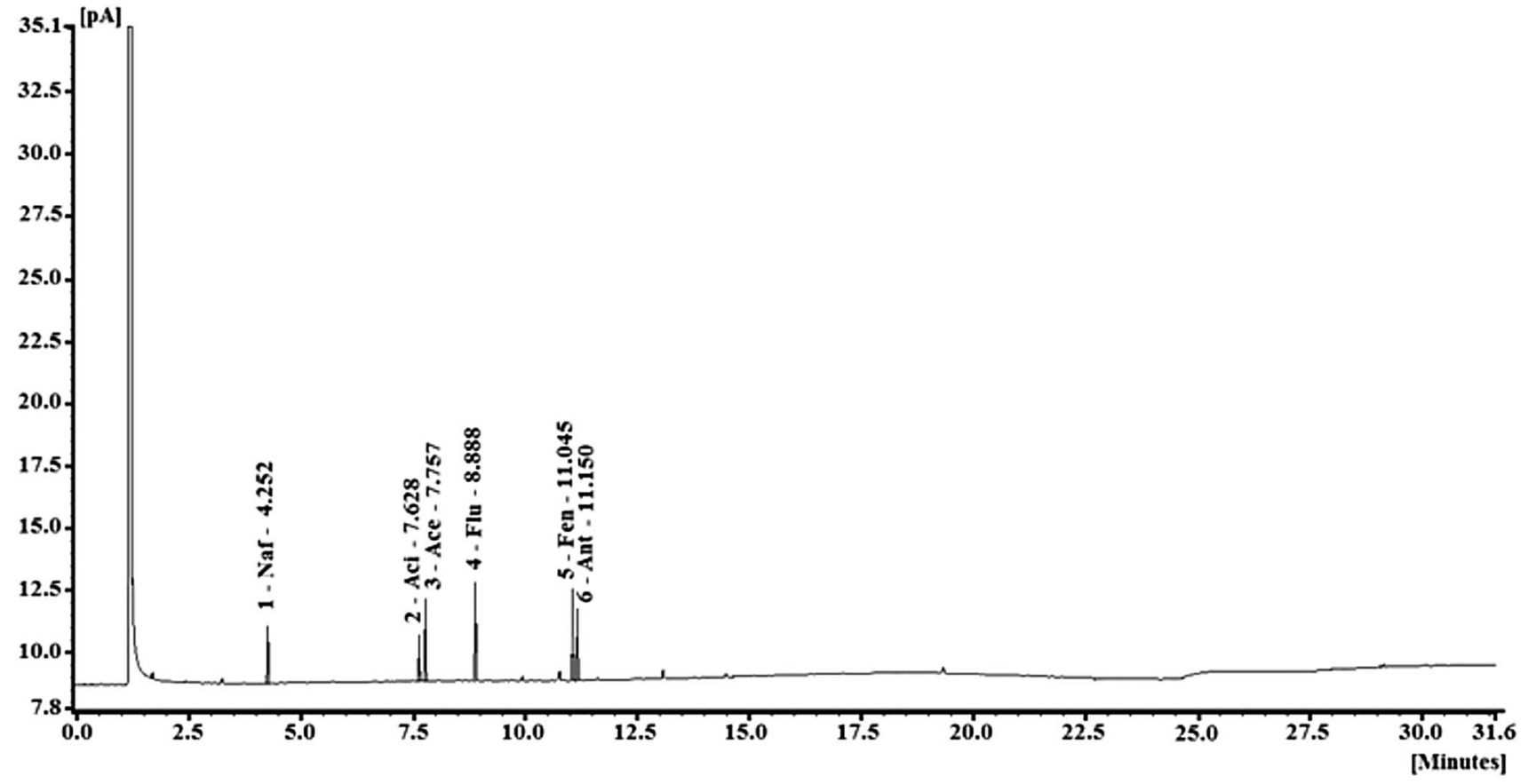

Fig. 5 Chromatographic profile obtained for groundwater sample (PR2) by GC-FID 
Table 6 PAH values determined by GC-FID in 17 groundwater samples after SPE extraction $\left(\mu \mathrm{L} \mathrm{L}^{-1} \pm \mathrm{SD}, n=3\right)$

\begin{tabular}{|c|c|c|c|c|c|c|c|c|c|c|c|}
\hline \multirow[t]{2}{*}{$\mathrm{PAH}$} & \multicolumn{11}{|l|}{ Samples } \\
\hline & MC1 & MC2 & MC3 & MC4 & MC5 & MC6 & PR1 & PR2 & PR3 & PR4 & PR5 \\
\hline Naf & $36.4 \pm 0.18$ & $<0.032^{*}$ & $<0.032^{*}$ & $8.3 \pm 0.15$ & $13.7 \pm 0.11$ & $20.6 \pm 0.09$ & $16.4 \pm 0.01$ & $19.3 \pm 0.02$ & $16.3 \pm 0.27$ & $<0.032^{*}$ & $13.5 \pm 0.10$ \\
\hline 2-BrNaf & $<0.042^{*}$ & $<0.042^{*}$ & $<0.042^{*}$ & $<0.042^{*}$ & $<0.042^{*}$ & $<0.042^{*}$ & $<0.042^{*}$ & $<0.042^{*}$ & $<0.042^{*}$ & $<0.042^{*}$ & $<0.042^{*}$ \\
\hline Aci & $10.4 \pm 0.06$ & $<0.047^{*}$ & $<0.047^{*}$ & $<0.047^{*}$ & $<0.047^{*}$ & $3.5 \pm 0.04$ & $2.8 \pm 0.02$ & $3.9 \pm 0.06$ & $3.5 \pm 0.13$ & $<0.047^{*}$ & $4.0 \pm 0.05$ \\
\hline Ace & $24.9 \pm 0.03$ & $<0.053^{*}$ & $<0.053^{*}$ & $12.1 \pm 0.09$ & $8.2 \pm 0.02$ & $11.2 \pm 0.08$ & $9.8 \pm 0.10$ & $12.8 \pm 0.14$ & $11.2 \pm 0.07$ & $<0.053^{*}$ & $8.3 \pm 0.10$ \\
\hline Flu & $<0.024^{*}$ & $<0.024^{*}$ & $<0.024^{*}$ & $<0.024^{*}$ & $4.9 \pm 0.09$ & $<0.024^{*}$ & $<0.024^{*}$ & $8.8 \pm 0.15$ & $<0.024^{*}$ & $<0.024^{*}$ & $<0.024^{*}$ \\
\hline Fen & $<0.036^{*}$ & $<0.036^{*}$ & $<0.036^{*}$ & $<0.036^{*}$ & $<0.036^{*}$ & $<0.036^{*}$ & $<0.036^{*}$ & $7.3 \pm 0.16$ & $5.4 \pm 0.09$ & $<0.036^{*}$ & $6.7 \pm 0.02$ \\
\hline Ant & $19.4 \pm 0.04$ & $<0.044^{*}$ & $<0.044^{*}$ & $<0.044^{*}$ & $<0.044^{*}$ & $<0.044^{*}$ & $5.6 \pm 0.18$ & $9.1 \pm 0.08$ & $5.8 \pm 0.08$ & $<0.044^{*}$ & $5.2 \pm 0.12$ \\
\hline Flt & $<0.026^{*}$ & $<0.026^{*}$ & $<0.026^{*}$ & $<0.026^{*}$ & $<0.026^{*}$ & $<0.026^{*}$ & $<0.026^{*}$ & $<0.026^{*}$ & $<0.026^{*}$ & $<0.026^{*}$ & $<0.026^{*}$ \\
\hline Pyr & $<0.033^{*}$ & $<0.033^{*}$ & $<0.033^{*}$ & $<0.033^{*}$ & $<0.033^{*}$ & $<0.033^{*}$ & $<0.033^{*}$ & $<0.033^{*}$ & $<0.033^{*}$ & $<0.033^{*}$ & $<0.033^{*}$ \\
\hline $\mathrm{BaA}$ & $<0.025^{*}$ & $<0.025^{*}$ & $<0.025^{*}$ & $<0.025^{*}$ & $<0.025^{*}$ & $<0.025^{*}$ & $<0.025^{*}$ & $<0.025^{*}$ & $<0.025^{*}$ & $<0.025^{*}$ & $<0.025^{*}$ \\
\hline Cry & $<0.095^{*}$ & $<0.095^{*}$ & $<0.095^{*}$ & $<0.095^{*}$ & $<0.095^{*}$ & $<0.095^{*}$ & $<0.095^{*}$ & $<0.095^{*}$ & $<0.095^{*}$ & $<0.095^{*}$ & $<0.095^{*}$ \\
\hline $\mathrm{BbF}$ & $<0.035^{*}$ & $<0.035^{*}$ & $<0.035^{*}$ & $<0.035^{*}$ & $<0.035^{*}$ & $<0.035^{*}$ & $<0.035^{*}$ & $<0.035^{*}$ & $<0.035^{*}$ & $<0.035^{*}$ & $<0.035^{*}$ \\
\hline $\mathrm{BaP}$ & $<0.045^{*}$ & $<0.045^{*}$ & $<0.045^{*}$ & $<0.045^{*}$ & $<0.045^{*}$ & $<0.045^{*}$ & $<0.045^{*}$ & $<0.045^{*}$ & $<0.045^{*}$ & $<0.045^{*}$ & $<0.045^{*}$ \\
\hline Ind & $<0.052^{*}$ & $<0.052^{*}$ & $<0.052^{*}$ & $<0.052^{*}$ & $<0.052^{*}$ & $<0.052^{*}$ & $<0.052^{*}$ & $<0.052^{*}$ & $<0.052^{*}$ & $<0.052^{*}$ & $<0.052^{*}$ \\
\hline DBahA & $<0.106^{*}$ & $<0.106^{*}$ & $<0.106^{*}$ & $<0.106^{*}$ & $<0.106^{*}$ & $<0.106^{*}$ & $<0.106^{*}$ & $<0.106^{*}$ & $<0.106^{*}$ & $<0.106^{*}$ & $<0.106^{*}$ \\
\hline BghiP & $<0.113^{*}$ & $<0.113^{*}$ & $<0.113^{*}$ & $<0.113^{*}$ & $<0.113^{*}$ & $<0.113^{*}$ & $<0.113^{*}$ & $<0.113^{*}$ & $<0.113^{*}$ & $<0.113^{*}$ & $<0.113^{*}$ \\
\hline$\Sigma \mathrm{HPA}$ & 91.1 & - & - & 20.4 & 26.8 & 35.3 & 34.6 & 61.2 & 42.2 & - & 37.7 \\
\hline \multirow[t]{2}{*}{ PAH } & & \multicolumn{10}{|l|}{ Samples } \\
\hline & & \multicolumn{2}{|c|}{ ST1 } & ST2 & \multicolumn{2}{|c|}{ CD1 } & \multicolumn{2}{|l|}{ CD2 } & \multicolumn{2}{|l|}{ MB1 } & MB2 \\
\hline Naf & & \multicolumn{2}{|l|}{$<0.032^{*}$} & $<0.032^{*}$ & \multicolumn{2}{|c|}{$11.4 \pm 0.06$} & \multicolumn{2}{|c|}{$12.8 \pm 0.14$} & \multicolumn{2}{|l|}{$<0.032^{*}$} & $<0.032^{*}$ \\
\hline 2-BrNaf & & \multicolumn{2}{|l|}{$<0.042^{*}$} & $<0.042^{*}$ & \multicolumn{2}{|c|}{$<0.042^{*}$} & \multicolumn{2}{|c|}{$<0.042^{*}$} & \multicolumn{2}{|l|}{$<0.042^{*}$} & $<0.042^{*}$ \\
\hline Aci & & \multicolumn{2}{|l|}{$<0.047^{*}$} & $<0.047^{*}$ & \multicolumn{2}{|c|}{$<0.047^{*}$} & \multicolumn{2}{|c|}{$<0.047^{*}$} & \multicolumn{2}{|l|}{$<0.047^{*}$} & $<0.047^{*}$ \\
\hline Ace & & \multicolumn{2}{|l|}{$<0.053^{*}$} & $<0.053^{*}$ & \multicolumn{2}{|c|}{$11.5 \pm 0.07$} & \multicolumn{2}{|c|}{$10.1 \pm 0.15$} & \multicolumn{2}{|l|}{$<0.053^{*}$} & $<0.053^{*}$ \\
\hline Flu & & $<0.024^{*}$ & & $<0.024^{*}$ & $<0 . C$ & $24^{*}$ & $<0.0$ & & $<0.024^{*}$ & & $<0.024^{*}$ \\
\hline Fen & & $<0.036^{*}$ & & $<0.036^{*}$ & $<0 . C$ & $36^{*}$ & $<0.0$ & & $<0.036^{*}$ & & $<0.036^{*}$ \\
\hline Ant & & $<0.044^{*}$ & & $<0.044^{*}$ & $<0 . c$ & $344^{*}$ & $6.7 \pm$ & .01 & $<0.044^{*}$ & & $<0.044^{*}$ \\
\hline Flt & & $<0.026^{*}$ & & $<0.026^{*}$ & $<0 . c$ & $26^{*}$ & $<0.0$ & & $<0.026^{*}$ & & $<0.026^{*}$ \\
\hline Pyr & & $<0.033^{*}$ & & $<0.033^{*}$ & $<0 . C$ & $33^{*}$ & $<0.0$ & & $<0.033^{*}$ & & $<0.033^{*}$ \\
\hline $\mathrm{BaA}$ & & $<0.025^{*}$ & & $<0.025^{*}$ & $<0.0$ & $25^{*}$ & $<0.0$ & & $<0.025^{*}$ & & $<0.025^{*}$ \\
\hline Cry & & $<0.095^{*}$ & & $<0.095^{*}$ & $<0.0$ & $995^{*}$ & $<0.0$ & & $<0.095^{*}$ & & $<0.095^{*}$ \\
\hline $\mathrm{BbF}$ & & $<0.035^{*}$ & & $<0.035^{*}$ & $<0 . c$ & $35^{*}$ & $<0.0$ & & $<0.035^{*}$ & & $<0.035^{*}$ \\
\hline $\mathrm{BaP}$ & & $<0.045^{*}$ & & $<0.045^{*}$ & $<0 . C$ & $045^{*}$ & $<0.0$ & & $<0.045^{*}$ & & $<0.045^{*}$ \\
\hline Ind & & $<0.052^{*}$ & & $<0.052^{*}$ & $<0 . C$ & $52^{*}$ & $<0.0$ & & $<0.052^{*}$ & & $<0.052^{*}$ \\
\hline DBahA & & $<0.106^{*}$ & & $<0.106^{*}$ & $<0.1$ & $106^{*}$ & $<0.1$ & & $<0.106^{*}$ & & $<0.106^{*}$ \\
\hline BghiP & & $<0.113^{*}$ & & $<0.113^{*}$ & $<0.1$ & $113^{*}$ & $<0.1$ & & $<0.113^{*}$ & & $<0.113^{*}$ \\
\hline$\Sigma \mathrm{HPA}$ & & - & & - & 22.9 & & 29.6 & & - & & - \\
\hline
\end{tabular}

*LOD = limit of detection; SD = standard deviation; abbreviations described in the subitem reagent, solutions and materials

Acknowledgements The authors thank the Foundation for Research Support of the State of Pará (FAPESPA, Pará, Brazil) and Vale S.A. (Call Notice No. 21/2008) for the scholarship granted to F. I. M. C. To FADESP/UFPA for the support in the expenses of translation.

\section{Compliance with ethical standards}

Conflict of interest The authors declare that they have no conflict of interest.

SN Applied Sciences
Ethical approval This article does not contain any studies with human participants or animals performed by any of the authors.

\section{References}

1. Campanha MB, Melo CA, Moreira AB, Ferrarese RFMS, Tadini AM, Garbin EV, Bisinoti MC (2010) Variabilidade espacial e temporal de parâmetros físico-químicos nos rios turvo, preto e grande no Estado de São Paulo, Brasil. Quim Nova 33:1831-1836 
2. Azevedo RP (2006) Uso de água subterrânea em sistema de abastecimento público de comunidades na várzea da Amazônia central. Acta Amazonica 36:312-330

3. Rebouças AC, Braga B, Tundisi JG (2006) Águas doces no Brasil: Capital ecológico, uso e conservação. Escrituras, São Paulo

4. Dórea HS, Bispo JRL, Aragão KAS, Cunha BB, Navickiene S, Alves JPH, Romão LPC, Garcia CAB (2007) Analysis of BTEX, PAHs and metals in the oilfield produced water in the State of Sergipe, Brazil. Microchem J 85:234-238

5. Forte EJ, Azevedo MS, Oliveira RC, Almeida R (2007) Contaminação de aquífero por hidrocarbonetos: Estudo de caso na Vila Tupi, Porto Velho - Rondônia. Quim Nova 30:1539-1544

6. Rego ECP, Netto ADP (2007) PAHs and BTEX in Groundwater of gasoline stations from Rio de Janeiro City, Brazil. Bull Environ Contam Toxicol 79:660-664

7. Cabral NMT (2007) Teores de $\left(\mathrm{NO}_{3}^{-}\right)$e amônio $\left(\mathrm{NH}_{4}^{+}\right)$nas águas do aquífero Barreiras nos bairros do Reduto, Nazaré e Umarizal - Belém/PA. Quim Nova 30:1804-1808

8. Carvalho FIM, Lemos VP, Dantas Filho HA, Dantas KGF (2015) Assessment of groundwater quality from the Belém based on physicochemical parameters and levels of trace elements using multivariate analysis. Rev Virtual Quim 7:2221-2241

9. Panero FS, Silva HEB (2008) Application of exploratory data analysis for the characterization of tubular wells of the north of Brazil. Microchem J 88:194-200

10. Albergamo V, Helmus R, De Voogt $P$ (2018) Direct injection analysis of polar micropollutants in natural drinking water sources with biphenyl liquid chromatography coupled to high-resolution time-of-flight mass spectrometry. J Chromatogr A 1569:53-61

11. Vollhardt KPC, Schore NE (2004) Química orgânica: estrutura e função. Bookman, Porto Alegre

12. Sharma BM, Melymuk L, Bharat GH, Prybilová $P$, Sánka $O$, Klánová J, Nizzeto L (2018) Spatial gradients of polycyclic aromatic hydrocarbons (PAHs) in air, atmospheric deposition, and surface water of the Ganges River basin. Sci Total Environ 627:1495-1504

13. Galitskaya IV, Pozdnyakova IA (2012) The pollution of groundwater and unsaturated zone rocks by oil products and PAH in urban areas. Water Resour 39:784-789

14. Nizzetto L, Lohmann L, Gioia R, Jahnke A, Temme C, Dachs J, Herckes P, Di Guardo A, Jones KC (2008) PAHs in air and seawater along a north-south atlantic transect: trends, processes and possible sources. Environ Sci Technol 45:1580-1585

15. Khan S, Aijun L, Zhang S, Hu Q, Zhu YG (2008) Accumulation of polycyclic aromatic hydrocarbons and heavy metals in lettuce grown in the soils contaminated with long-term wastewater irrigation. J Hazard Mater 152:506-515

16. Seruto C, Sapozhnikova Y, Schlenk D (2005) Evaluation of the relationships between biochemical endpoints of $\mathrm{PAH}$ exposure and physiological endpoints of reproduction in male California Halibut (Paralichthys californicus) exposed to sediments from a natural oil seep. Mar Environ Res 60:454-464

17. Samia K, Dhouha A, Anis C, Ammar M, Rim A, Abdelkrim C (2018) Assessment of organic pollutants (PAH and PCB) in surface water: sediments and shallow groundwater of Grombalia watershed in northeast of Tunisia. Arab J Geosci 11:1-11

18. Filipkowska A, Lubecki L, Kowalewska G (2005) Polycyclic aromatic hydrocarbon analysis in different matrices of the marine environment. Anal Chim Acta 547:243-254

19. Moroles NED, Barbosa JMA, Ulloa HG (2001) Método analítico para detectar hidrocarbonetos aromáticos policíclicos em água potável. Cienc UANL 4:420-425

20. International Agency for Research on Cancer (IARC) (2008) Agents reviewed by the IARC monographs, pp 1-99. http:// monographs.iarc.fr/ENG/Classification/crthallalph.php Accessed 22 Dec 2013
21. Cetin B, Yurdakul S, Gungormus E, Ozturk F, Sofuoglu SC (2018) Source apportionment and carcinogenic risk assessment of passive air sampler-derived PAHs and PCBs in a heavily industrialized region. Sci Total Environ 633:30-41

22. Geiss O, Senaldi C, Bianchi I, Lucena A, Tirendi S, Barrero-Moreno $J$ (2018) A fast and selective method for the determination of 8 carcinogenic polycyclic aromatic hydrocarbons in rubber and plastic materials. J Chromatogr A 1566:13-22

23. Baird C (2006) Química Ambiental. Bookman, Porto Alegre

24. Re-Poppi N, Stroher GL, Raposo JL, Souza JBG (2007) Determination of polycyclic aromatic hydrocarbons by gas chromatography-ion trap tandem mass spectrometry and source identifications by methods of diagnostic ratio in the ambient air of Campo Grande, Brazil. Microchem J 86:112-118

25. Zhang S, Zhang Q, Darisaw S, Ehie O, Wang G (2007) Simultaneous quantification of polycyclic aromatic hydrocarbons (PAHs), polychlorinated biphenyls (PCBs), and pharmaceuticals and personal care products (PPCPs) in Mississippi river water, in New Orleans, Louisiana, USA. Chemosphere 66:1057-1069

26. Cheng J, Yuan T, Wu Q, Zhao Z, Xie H, Ma Y, Ma J, Wang W (2007) PM10-bound polycyclic aromatic hydrocarbons (PAHs) and cancer risk estimation in the atmosphere surrounding an industrial area of Shanghai, China. Water, Air, Soil Pollut. 183:437-446

27. Makós P, Przyjazny A, Boczkaj G (2018) Hydrophobic deep eutectic solvents as "green" extraction media for polycyclic aromatic hydrocarbons in aqueous samples. J Chromatogr A 1570:28-37

28. Minoia C, Magnaghi S, Micoli G, Fiorentino ML, Turci R, Angeleri S, Berri A (1997) Determination of environmental reference concentration of six PAHs in urban areas (Pavia, Italy). Sci Total Environ 198:33-41

29. Gebara SS, Ré-Poppi N, Nascimento ALCS, Júnior JLR (2013) Métodos para análises de HPA e BTEX em águas subterrâneas de postos de revenda de combustíveis: Um estudo de caso em Campo Grande, MS, Brasil. Quim Nova 36:1030-1037

30. Lanças FM (2004) Extração em Fase Sólida (SPE). RiMa, São Carlos

31. Campos CDM, Campos RPS, Silva JAF, Jesus DP, Orlando RM (2015) Preparo de amostras assistido por campo elétrico: Fundamentos, avanços, aplicações e tendências. Quim Nova 38:1093-1106

32. Caldas SS, Gonçalves FF, Primel EG, Prestes OD, Martins ML, Zanella R (2011) Principais técnicas de preparo de amostra para a determinação de resíduos de agrotóxicos em água por cromatografia líquida com detecção por arranjo de diodos e por espectrometria de massas. Quim Nova 34:1604-1617

33. Barrionuevo WR, Lanças FM (2001) Extração em fase sólida (SPE) e micro extração em fase sólida (SPME) de piretróides em água. Quim Nova 24:172-175

34. Queiroz SCN, Collins CH, Jardim ICSF (2001) Métodos de extração e/ou concentração de compostos encontrados em fluidos biológicos para posterior determinação cromatográfica. Quim Nova 24:68-76

35. American Public Health Association (APHA) (2005) Standard Methods for the examination of water and wastewater. American Water Works Association (AWWA) and Water Environment Federation (WEF), 21st edn. Washington

36. United States Environmental Protection Agency (USEPA) (1998) Test methods on-line-USEPA 3535A: solid-phase extraction (SPE). http://www.epa.gov/homeland-security-research/epamethod-3535a-sw-846-solid-phase-extraction-spe. Accessed 12 Jan 2013

37. United States Environmental Protection Agency (USEPA) (1896) Test methods on-line-USEPA 8100: polynuclear aromatic hydrocarbons. http://www.epa.gov/hw-sw846/sw-846-test-metho d-8100-polynuclear-aromatic-hydrocarbons. Accessed 12 Jan 2013 
38. Skoog DA, Holler FJ, Nieman TA (2002) Princípios de Análise Instrumental. Bookman, Porto Alegre

39. Ministério da Saúde (MS) (2011) Portaria n 2914 de 12 de dezembro de 2011. http://bvsms.saude.gov.br/bvs/saudelegis /gm/2011/prt2914_12_12_2011.html. Accessed 12 Nov 2016

40. Conselho Nacional de Meio Ambiente (CONAMA) (2008) Resolução no 396 de 3 de abril de 2008. http://www.mma.gov.br/ port/conama/legiabre.cfm?codlegi=562. Accessed 12 Nov 2016

41. Brum DM, Castella RJ, Netto ADP (2007) Multivariate optimization of a liquid-liquid extraction of the EPA-PAHs from natural contaminated waters prior to determination by liquid chromatography with fluorescence detection. Talanta 74:1392-1399

42. Yunker MB, Macdonald RW, Vingarzan R, Mitchell RH, Goyette D, Sylvestre $S$ (2002) PAHs in the Fraser river basin: a critical appraisal of PAH ratios as indicators of PAH source and composition. Org Geochem 33:489-515

Publisher's Note Springer Nature remains neutral with regard to jurisdictional claims in published maps and institutional affiliations. 